\title{
Surtitling today: new uses, attitudes and developments
}

\author{
Marta Mateo \\ University of Oviedo
}

Surtitling has exerted a noticeable twofold effect on the opera world, in which it originated: it has contributed substantially to increasing the number of opera goers, making opera more accessible and "audience-friendly" and changing audiences' expectations towards their operatic experience, which has in turn affected the reception of works in the audience's native language; secondly, it has brought about innovations in opera production, introducing new languages and pieces in opera houses. Besides, surtitles have now been put to new uses, as some theatre productions have adopted them enabling drama to travel more extensively. This article will focus on the changes surtitling has produced in the contexts using it, the impact of technical advances on its own production and reception, as well as on its new consumers and uses.

\section{Surtitling as Audiovisual Translation}

More than twenty years have elapsed since surtitles were first introduced in the opera world in which they originated, so we now have some perspective to analyse their impact on audience reception and the changes they may have brought about in the settings in which they are used. This will be the object of the present article, which will also study the developments surtitles themselves have seen in their production and their role as a communication tool.

Surtitling is a fairly recent innovation in Audiovisual Translation; Gambier (2003: 172-177) includes it in his group of challenging types of AVT, together with e.g. intralingual subtitling, live subtitling and audio description, as opposed to dominant types such as dubbing, voice-over or interlingual subtitling. It shares, however, many features with all types of audiovisual communication, regarding not just its production and reception but also the way in which it is studied. Thus, the production of surtitles is determined by the fact that they form part of a multisemiotic product, in which the verbal target text goes hand in hand with aural and visual elements which were originally created for the source text and are carried over to the target context with no alterations. The presence of these other semiotic signals constrains translation choices and is also the reason for the functional nature of all audiovisual target texts: as these are not autonomous entities and can only be understood as one more element in the multisemiotic complex, their production is marked by the need for efficiency and for 
coherence and synchronization with all other elements. As Riitta Virkkunen puts it (2004: 93),

surtitling has a very specific function: The audience uses the surtitles for communicating with other symbolic modes used in the performance for creating meanings. In practice this means that surtitles mostly serve as a medium for the verbal content but also help to comprehend music and acting.

Of all AVT types, surtitling is closest to subtitling, from which it is derived, and it can also be defined "as (1) written, (2) additive, (3) immediate, (4) synchronous and (5) polymedial translation", borrowing Gottlieb's definition of that earlier translation form (1997: 70). The reception of surtitles is marked by the transient and complex nature of the opera or theatre performance: readers can only interpret these texts together with what is happening on the stage and they cannot control the pace of the reception, which is in the hands of the surtitler, who in turn follows the tempo of the stage interpretation. Surtitles, then, offer further evidence of the fragmented reading that Gambier \& Gottlieb (2001: xviii) identify as characteristic of much of today's written reception, with viewers jumping from subtitles (or surtitles) to the picture (or stage) and from one title to another. "Thus, the effort to understand is no longer focused on only one system of signs, on only one logic" (ibid.).

Like many other types of audiovisual translation, "[s]urtitling opera is about seeing and hearing, reading and writing" (Virkkunen 2004: 96) and it can only be approached from a multimodal view of opera texts. Besides, the characteristics of the reception context (cf. above) imply a strong influence of the target audience on the production phase. In screen translation ${ }^{1}$ in general, and in theatre translation too, "fidelity is subordinated to the communicative needs of an audience" (Gambier 2003: 185). In opera - and theatre - surtitling, this subordination is therefore doubly felt. This reinforces the need to study it within the target communicative situation, so that we may take into account the target audiences' expectations as well as all the participants' roles in the production and reception stages more directly. This will be the approach taken in the present article, analysing the changes, contexts and new uses of surtitling.

\section{Surtitling in the opera world: influence and development}

\subsection{Impact on the reception context}

Like other 'audiovisual' translation types, surtitles originated from a reception need; more specifically, they made their appearance as translation texts in the world of opera, an art form which has often implied a foreign language experience to most audiences in many countries. They were 
therefore first created as target texts which would facilitate comprehension of the opera's plot with a very discrete presence at the theatre, and were never meant to replace the source text, but to complement it; this explains their functional nature, which they share with subtitles (Díaz Cintas 2003: 212). The impact of surtitling on opera reception has been very powerful: it has contributed significantly to increasing the number of opera goers (see Bonwit 1998; Dewolf 2001: 187; Low 2002: 98-99)2 , attracting new social sectors to this art thanks to the greater accessibility it affords (Carlson 2000: 83; Dewolf 2001: 180; Mateo 2001: 45), as well as enriching their operatic experience and changing the audience's expectations.

This impact has in turn affected the reception of works in the audience's native language, for the original function of surtitles has now been extended to that of facilitating communication in situations not necessarily involving translation. Indeed, many opera houses now use surtitles even for operas performed in the language of the audience. This is the case of the Royal Opera House in London or the Teatro Real in Madrid, for instance. We can thus distinguish, as is done in subtitling, between interlingual and intralingual surtitling. Intralingual subtitling, however, is mostly intended for the deaf and hard of hearing or, in multilingual communities, to help immigrants improve their command of the local language (Gambier 2003: 174); on the other hand, intralingual surtitling is clearly derived from the effect interlingual surtitles have had on reception in most opera houses in the Western world, for they have changed the audience's expectations of their opera experience. If, not many years ago, opera goers assumed noncomprehension as part of this experience (unless they knew the pieces by heart - which was not uncommon - or studied the libretto before the performance), today's audiences show a desire to understand the verbal text at the same time as they receive the music and seem to have realised that the full comprehension of the opera can only be achieved through the simultaneous interpretation of all semiotic signs in it. Although I cannot ground this statement on any audience research as yet, I believe it may be inferred from the fact that "most opera houses mention [surtitles] in their bills, brochures and/or webpages and in that surtitles now have a bearing on ticket prices (which shows that audiences are not prepared to pay the same price for seats which do not offer a view of surtitles as for those which do)" (Mateo 2007: 178). Some opera companies actually specify in their programmes which rows do not offer a view of surtitles (e.g. the Glyndebourne Touring Opera, see Martínez forthcoming), which illustrates the important part these now play in the enjoyment of this art. Indeed, there have been cases of malfunctions during a performance (e.g. a projector which suddenly stops working, power failures, etc.) which have made the audience miss half of the show, some later demanding their money back - as Bonwit (1998) recalls happened with a production of Electra by The Washington Opera ${ }^{3}$. The appearance of intralingual surtitles is due both to this new attitude and to the difficulty of grasping many of the words in a sung text particularly those in high registers -, a difficulty which some consider in- 
herent to singing and others attach to the deterioration of singers' diction (cf. infra).

A good example of this situation can be found in Spain, where intralingual surtitles are now commonly used for the Spanish national genre of lyrical drama, zarzuela. The Teatro de la Zarzuela in Madrid has been projecting Spanish surtitles in zarzuela performances for a few years, and other theatres and festivals have now followed suit. In an appearance at the Spanish Senate on 2 June 1999, Tomás Marco, General Director of the INAEM (the National Institute of Theatre Arts and Music), composer and musicologist, defended the introduction of surtitles for performances of Spanish lyrical drama, in imitation of what was already being done for foreign operas, on the grounds that singing voices are not easily understood ${ }^{4}$. This is in fact one of the reasons given by the organizers of the Festival Lírico at the Teatro Campoamor in Oviedo for the recent introduction of intralingual surtitles: in their view, today's singers have gained in good voice but have lost quality of diction, which has sometimes meant that audiences have been unable to follow the less widely known zarzuelas (personal communication). They cite the need to understand the text as another reason for this decision, since they consider it as part of the artistic experience. The expenditure of surtitling is, according to them, well worth the effort.

A new role and new consumers - those who expect surtitles even when the language of the opera is not a foreign one to them - have therefore been incorporated into the surtitling of musical texts. Audiences' attitudes towards surtitles in general, however, have differed considerably in the various opera contexts which first introduced them: from expectant enthusiasm in Canada - where they were first used in the Western world, in 1983 -, to New York's initial reluctance and Britain's mixed reaction and recent controversy about them, as against the very positive welcome they have had in other European countries like Spain. Most negative reactions initially came from some critics, singers and directors who considered surtitles as an awkward form of interference in the overall reception of the opera (see Mateo 2002 and Martínez forthcoming). Criticisms have later centred, at least in some countries like Britain, mostly on surtitles in the language of the performance, which are seen as superfluous and an insult to the singers' acting and clarity of diction. This was chiefly the object of the controversy that took place in Britain at the turn of this century, prompted by a Royal Opera House production of Britten's Billy Budd, which was sung in English with English surtitles. We may here quote an extract from one of Andrew Clements's reviews (2000), as an example of the numerous articles and letters to the editor published in British newspapers on the contentious issue of intralingual surtitles at the time (see Mateo 2002 and Martínez forthcoming):

If the battle against English surtitles for foreign language works has to be conceded now - there's no doubt comprehension is increased for non-linguists - introducing them for works sung in the vernacular is 
another matter. When opera ceases to be a medium in which the drama is presented through the symbiosis of the music and words, and instead is turned entirely into an exercise in reading, with the addition of some more or less engaging background music, then the medium is devalued, and it really will become museum art of a vacuous and purely decorative kind.

Of the same opinion as the English music critic is a Spanish reviewer of zarzuela productions at the Teatro de la Zarzuela in Madrid (Mejías 2005):

Y éste es el momento para reflexionar sobre la penosa necesidad a la que ha tenido que llegar el Teatro de la Zarzuela, instalando sobretítulos en sus producciones en castellano; ¿qué ocurre con la manera de cantar zarzuela?, ¿quizás se ocupan del género artistas que vienen mayoritariamente de otros terrenos como el operístico? La realidad es que no hay en España una escuela de canto dedicada al más grande de nuestros géneros musicales, la zarzuela, y que ante esta situación el público demanda comprender los espectáculos por los que pagan. La zarzuela está en alza; es hora de que el Ministerio de Cultura, que rige este teatro y los conservatorios, tome medidas.

[And this is the moment to reflect on the need which the Teatro de la Zarzuela has recently sadly felt, to introduce (Castilian Spanish) surtitles in its Castilian productions; what is the matter with the way zarzuela is sung? ¿is it that it is being sung by artists coming mostly from other fields, such as opera? The fact of the matter is that Spain has not got a singing school devoted to the greatest of our musical genres, zarzuela, and that, faced with this situation, audiences demand to be able to understand the shows they are paying for. Zarzuela's popularity is on the rise; it is high time the Ministry of Culture, which is in charge of that theatre and of public music schools, took measures.] (Translation MM).

Some crucial points are raised in this comment: the reviewer does not criticise the policy of introducing intralingual surtitles as such but the factor which, in his opinion, has made it inevitable, namely, the singers' poor diction; and the influence of opera seems to loom large, both regarding the introduction of surtitling and the lack of clarity in the conveyance of the text. Interestingly, the organizers of the zarzuela festival in Oviedo also pointed out different attitudes in singers towards surtitles: those coming from the opera world are not upset by the presence of intralingual surtitles in their zarzuela performances - they are used to singing with surtitling in opera productions -, while singers specialised in zarzuela are offended initially - although they eventually get used to their vocal texts being duplicated on a screen.

This is connected to audiences' - and singers' - expectations towards these two artistic experiences: at least in Spain, most opera audiences 
have traditionally been resigned to not understanding the texts they watched/heard on the stage (although this attitude is now changing precisely under the influence of surtitling), while zarzuela spectators have always been used to following the words together with the music. This is probably due to the different nature of the two genres: the presence of spoken dialogue in zarzuela pieces makes the dramatic component in them more noticeable than in opera, while the permanent presence of music in opera texts has often resulted in the underrating of their dramatic nature. Moreover, the fact that zarzuela has traditionally appealed to members of all social classes in Spain - vs the more elitist position occupied by opera as a form of entertainment - can also be quoted as one of the factors for these different attitudes. Pierre Bourdieu's theory on the sociology of arts has proved to be highly relevant to study the place of sung translation in Spain's opera world. Mateo (2001: 43-45) explained this position in terms of the audiences' differing attitudes towards and perception of the various musical genres (opera vs musicals), using Bourdieu's opposition between distinguished and vulgar consumption (1988: 175). His concept of barbaric taste (Bourdieu 1988: 496) - as that which rejects intellectualism and pedantry and prefers accessibility and comprehension in cultural consumption - might also here explain the relatively unproblematic introduction of intralingual surtitles in zarzuela productions, as opposed to the controversy they provoked in opera productions in Britain.

Audiences' attitudes towards surtitles have therefore differed depending on the country ${ }^{5}$, on whether they are a translation tool or an intralingual comprehension aid and on the social/artistic conception of the genre in which they are used. Curiously, the introduction of surtitling in opera houses seems to be changing some of these conceptions. As I pointed out in Mateo (2001: 45) and cf. infra,

It is interesting to see then that the connection established by Bourdieu between the intrinsic difficulty of a work of art and the elitism of the corresponding social group attracted by it seems to apply here too, as once surtitles have started to be used in opera houses, making the understanding and enjoyment of operas more accessible, the social group attending opera performances has widened and these have become less of an exclusive property of a certain social class.

Most of today's opera goers in the Western world expect and demand surtitles. And opera houses which have not yet introduced them are now criticised for it ${ }^{6}$. Bonwit (1998) sums up the evolution observed in the reception of surtitles soon after their introduction in the USA:

When translation titles were first suggested [at the Kennedy Center in Washington D.C.], people thought that it was tacky. If you didn't know the story and couldn't follow it during the performance, you were just out of it and didn't deserve to be at the opera. There was 
also objection that the titles distracted the audience from the singer. However, the use of titles has greatly enlarged the opera audience. As an opera buff and a regular at The Washington Opera, I now have a greater appreciation for the Surtitles.

But the benefits of surtitling for opera have not been felt on the reception side only. Surtitling has also allowed theatres and companies to cut costs, since surtitles are considerably cheaper than singable translations. Besides, it is offering them more leeway when determining their repertoire since "opera companies [now feel] under less constraint to stick to the "household name' operas [...] which the public would allegedly know already" (Low 2002: 99); and languages other than Italian, French or German are now more frequently heard in opera houses. All this has led to a revitalization of opera, which is attributed by various researchers, surtitling firms and opera managers and directors to the existence of surtitles.

Some critics, however, observe a negative impact of surtitling on sung translation, the other translation type used for musical texts in some countries: "Surtitles have become such a part of opera culture that sung translations [in the English-speaking world] seem almost exotic", complains Everett-Green (2004), who believes that opera in English, both in Britain and in North America, has suffered a severe blow due to the introduction of surtitles in opera houses. His greatest concern, however, is for new originally English operas: "When audiences are too lazy to accept even Peter Grimes without projected text, why would they show more patience for a piece by someone they've never heard of?" (ibid.).

On the other hand, the introduction of surtitles in Spain's opera houses is probably the motivation behind the more frequent presence of subtitled opera transmissions on Spanish television nowadays. Opera lovers are now used to a watching-reading reception of performances, and this has made TV broadcasts of operas - which were very rare only a few years ago - and the subtitles in them (in a dubbing country) more acceptable. My impression is that these subtitled transmissions have not been prompted by the presence of subtitling in other television programmes - still very rare - but, rather, by that of surtitling in the theatre productions of these texts. In other words, it appears to be the genre, rather than the medium, that has favoured their presence on Spanish television. It would seem that there is a form of mutual influence among these translation types, as surtitling itself has its own origins in the appearance of subtitles in cinema and in television broadcasts, but this requires further investigation.

\subsection{Developments on the production side}

The technology of surtitling has also experienced some changes which have affected both reception and production. Legibility has greatly improved thanks to the new software and projection systems. In most countries, the original slides were first replaced by computer-generated texts which 
solved some of the problems the previous system had (Mateo 2002 and Mateo 2007), making it easier, for instance, to introduce textual changes in titles to adapt them to different productions. Some opera houses and surtitling firms have developed their own software systems to generate the titles, but many now use Power Point, which has remedied the rigidity of earlier computer systems for things such as the number of lines per title and of characters per line, and the varying conventions of punctuation marks in each language.

Power Point, however, - or rather, the use some surtitlers make of it - raises some interesting questions regarding surtitling reception and production. The flexibility in the amount of text and number of lines and characters this system affords has encouraged some surtitlers to include a greater part of the libretto in their surtitles than they used to with previous computer systems. This is, at least, one of the most noticeable effects the introduction of Power Point has had in the opera season in my hometown, Oviedo. It probably responds not just to the possibilities offered by the new system but also to the fact that, of the two surtitling strategies which Virkkunen (2004: 94) observes in opera houses - one "that supports the [...] conception of the libretto being the source text of surtitles" as opposed to that which "sees surtitles as being part of the Gesamtkunstwerk of opera and aims at integrating them into the particular staging" -, Oviedo's opera house seems to favour the former. Now, this has an obvious impact on reception for, "if a spectator chooses to read the surtitles, the more titles there are the more time s/he needs for reading them; naturally, that time is taken away from interpreting other semiotic modes in the performance" (Virkkunen 2004: 93). If we define effectiveness in relevance theory terms, i.e. "the greater the viewers' processing effort, the lower the relevance of the translation" (Gambier 2003: 185), then this type of strategy is definitely less effective and relevant (in a relevance-theory sense). This is why Virkkunen (2004) is clearly in favour of the other strategy, which integrates surtitles into a particular stage interpretation, since it focuses on the essential part of the libretto in order to allow the audience more time to take in all the other signs in the performance too.

However, although no reception study has yet been made to measure the audience's satisfaction with this change in Oviedo's opera house, the fact that no comments have appeared in the reviews, articles, letters to the editor and opera gatherings frequently published in the local papers during the opera season, inclines me towards the view that the audience are content with, or indifferent to, the new texture of surtitles. My impression has been reinforced by the fact that some members of the season's organizing committee have expressed their satisfaction at the greater part of the libretto which could now be provided above the stage thanks to the introduction of Power Point (personal communication). This raises the question of how we are to measure reception and acceptability in AVT and of what we actually mean by 'reception' (see Gambier 2003: 183, 185). Most of those involved in the study or creation of surtitles believe the main role of these is to en- 
able audiences to more fully enjoy the opera performance. Surtitles therefore ought to complement all the other signs of the production without causing too much distraction. But do audiences actually expect the same? Or rather, do all participants and viewers perceive the role and constraints of surtitles in the same way?

It is, in fact, a matter of expectations, as Gambier (2003: 186) says of the reception of AVT in general. And socio-cultural, attitudinal, perceptual, and psychological aspects - which Gambier recommends for the study of subtitle reception (2003: 185) - must be considered here too. It may be the case that opera-goers expect surtitles to aid their comprehension of the opera, as well as for the texts to be credible, and that credibility may be judged in terms of the portion of libretto the surtitles contain. The problem of distraction may thus be secondary to credibility - an important aspect in matters of acceptability - in audiences' values and expectations for surtitling, as opposed to many stage directors', surtitlers' and researchers'. So we may have to distinguish between recipients' expectations and those of the human agents involved in the process, for they may not always coincide, as well as between the different types of agents taking part in the production. Indeed, the "institution" which controls the norms operating in the translation of a given genre and/or culture cannot be ignored in AVT research (Karamitroglou 2000: 81):

Both the 'institution' and the 'market' stand outside the actual production of translation as they are not the agents who actually produce the target text. They influence, however, both the agents/textproducers and the recipients/text-consumers by formulating their mutual expectations and presuppositions.

In this respect, the translation strategy chosen by the opera house in Oviedo may also respond to a conception of surtitles on the part of the opera season's organizers, who commission them for it, as texts which "aim at providing the audience with as objective information about the libretto as possible", the conception Virkkunen (2004: 94) identifies at the Royal Opera House in Covent Garden. And this strategy may be ascribed to a "policy which regards the surtitles as belonging to the neutral services offered by the opera house; therefore they must not mediate the artistic ideas of the director" (ibid.). The surtitler's professional background - whether s/he comes from the music world or the translation sphere, for instance - may also have a bearing on his/her expectations and conception of surtitles, and hence on their final shape. Nevertheless, as "[n]o research has yet been carried out on the different expectations of opera lovers and novices when they read surtitles" (Gambier 2003: 176), the whole issue of reception still needs further investigation.

Interestingly, one informal online survey was carried out among the members of a Spanish internet forum on opera in 2006 (at http:// www.operaactual.com, 14 May 2006), concerning the language question in 
surtitling at Barcelona's Teatre del Liceu. The discussion sprang from the introduction of another recent technical innovation: the small seat-back screens, which have eliminated some of the problems that the traditional projection on a screen above the proscenium presents. These individual screens provide surtitles to viewers in seats with a restricted view, they can be turned on and off at pleasure - so not all members of the audience are forced to watch titles -, they are unobtrusive - as the screens are designed so as not to be visible from neighbouring seats - and they may simultaneously transmit titles in eight languages, which the opera viewer selects. This last factor makes them particularly appropriate for multicultural or bilingual communities. New York's Metropolitan Opera House was indeed the first theatre to introduce them, in 1995, and Barcelona's Liceu did in 2002, offering a choice between translations into Catalan, Spanish and English. The introduction of the seat-back screens, however, has not led to the disappearance of the above-the-proscenium screen at the Liceu, so the two projection types co-exist, the latter showing only Catalan surtitles. This was, in fact, the topic for discussion on this internet forum, which provided the following survey ${ }^{7}$ (translation MM):

Surtitling at the Liceu should be:

-in Catalan, as it is: $33 \%$ [7 votes ]

-in Castilian Spanish: 61\% [13 votes]

-there shouldn't be any surtitles, as in the good old days: $0 \%$

[0 votes]

-I don't care, I never take any notice of them!!: 4\% [1 vote]

Total number of votes: 21

The participants in the discussion made some relevant comments on different points concerning surtitling, a selection of which is offered (because of the scant attention surtitling receives in Spanish newspapers or specialised journals) in the following endnotes: the linguistic issue ${ }^{8}$; the advantages and disadvantages of seat-back screens ${ }^{9}$; the need, or lack thereof, for surtitling in opera ${ }^{10}$; and the type of opera as a determining factor for this need ${ }^{11}$.

The comments on the last two issues suggest that translation 'recipients' in AVT research should not merely be classified in terms of the different translation types they are used to watching - e.g. subtitling vs dubbing, surtitling $v s$ sung translation - but also in relation to genres (see Gambier 2003: 185). Indeed, opera-goers' expectations about surtitling may be quite different from those of other more recent consumers of this translation type, as we will see in the next section. 


\section{Surtitling in drama translation}

Surtitles have meanwhile been put to new uses outside the opera context: some theatre productions have also started using this translation tool, enabling drama to travel more extensively. Theatre surtitling ${ }^{12}$ provides us with some interesting material for analysis regarding the way in which it differs from opera surtitling, as well as its influence on audience reception and theatre production. Moreover, some new uses have developed for surtitling in the theatre context which open up exciting possibilities for this AVT type as well as for theatre performance.

In order to study this development in surtitling, I prepared a questionnaire focusing on the macro-structural level of the target context (Díaz Cintas 2003: 321-325), which would generate some qualitative data about the situation in which theatre surtitling is produced and received. The questionnaire inquired about the participants in the process, their role and that of surtitles in this context, and the factors and beliefs which determine translation decisions and surtitling reception. As Karamitroglou (2000: 94) suggests for the investigation of norms in AVT, qualitative analysis is useful for it can shed "light on the way these individual products come to be released, who is actually involved in their production, and who they are aimed at." The questionnaire was sent out to several theatres, international theatre festivals and surtitlers in Spain, as well as to the British Council in Madrid since it sponsors many of the tours of British companies visiting Spain. Nine responses were received: from the people responsible for arranging the surtitling process in three festivals and three theatres, from two surtitlers, and from the British Council ${ }^{13}$. Some of the answers came over the telephone so the questionnaires actually took the form of interviews, which provided more information than the written questions would probably have elicited.

The first two questions ${ }^{14}$ were devoted to identifying the human agents involved in theatre surtitling, something that is not always easy to do as AVT is characterised by teamwork (Gambier \& Gottlieb 2001: xi), with a varying number of individuals intervening in the translation process and contributing to the final shape of the product (Karamitroglou 2000: 71). In the case of theatre festivals, it is always the organizers (the festival's production or programming departments) that commission the surtitling. With theatres, if it is the theatre that engages a particular foreign company to perform at their venue, then it is usually the theatre's production department that commissions the surtitles. On the other hand, if the theatre is housing a festival, it is the festival that provides the whole show (including the surtitles). Sometimes a theatre's production travels to other theatres, taking the surtitles (which form part of the production) along with it. It is therefore hardly ever the foreign company that initiates the translation process. However, it does at times interfere: according to the organisers of Barcelona's Festival Grec, some theatre companies refuse to have surtitling on artistic grounds (because of the intrusive nature of surtitles), in which case the fes- 
tival has to assess if it is worth inviting the company in question. As regards the second issue, practically all the theatres and festivals commission the surtitling to one of the various specialised firms now operating in Spain. The Festival Grec sometimes prefers - on quality grounds - to commission the target texts to a freelance translator while they take charge of the technical side themselves.

Four questions were asked ${ }^{15}$ concerning the technical aspects of the surtitling process. As regards the software system used, there are now a few specific programmes registered by some of the surtitling firms. Power Point is resorted to by some theatres when they do the surtitling themselves. The projection is usually made on a LED screen. But the people in charge of arranging the surtitling at the Festival Grec are particularly sensitive to the intrusion of surtitles in the scenery, so they take great care to minimize this as much as possible, adapting both the position of the screen (above/below/on one side of the stage) and its lay-out. Frequently the LED screen is replaced there by a hand-made one consisting of a simple wooden board and a black cloth, which can be enlarged or reduced in size depending on the set design. The person in charge of the projection in most theatres is usually a technician from the surtitling firm, not necessarily the same person who has made the titles: the firms often have a team of translators and then some technicians who travel to the theatres which have commissioned the surtitling and stay there until the foreign company leaves. If the commission is made to a freelance translator, it is sometimes the translator him/herself that takes charge of the projection and at other times a technician from the theatre, who may work hand in hand with a colleague from the company.

The fourth technical question concerned the problem of unexpected changes in the performance: if the person projecting the surtitles is the translator, s/he may realise that a change is being introduced live on stage and not project the original corresponding title. This will depend, however, on his/her ability to respond quickly and on the type of change required. According to '36caracteres', the company that takes care of the surtitling for the Festival Escena Contemporánea in Madrid, an experienced surtitler may achieve almost perfect synchronization. They reckon that, of a total of 1000 titles, only one or two will go wrong, even with several unexpected changes. On the other hand, those theatres in which the projection is in the hands of a technician who has not prepared the titles and/or does not know the play, admit there is nothing that can be done when unexpected changes occur. There is simply no time to react and the originally planned surtitle will be projected anyway. Sometimes, changes are introduced in lastminute rehearsals, only a couple of hours before the first night. In that case, the surtitle which had been prepared will probably not be projected, as the change is anticipated but there is no time to adapt the surtitle. If the change is going to be a permanent alteration to the text, then the surtitle will be adapted for the performance of the following day. 
As regards the issue of the impact surtitling might have had on the festival's/theatre's programming ${ }^{16}$ - i.e. whether the projection of surtitles has resulted in a greater presence of foreign companies -, surtitlers and surtitling firms are of the opinion that this translation tool has enabled drama to travel more extensively and that this can clearly be noticed in Spanish festivals and theatres. The agents responsible for commissioning surtitling at theatres and festivals, however, do not completely agree that it has had a direct impact on this presence. In some cases, economic reasons are quoted as the main reason for the greater or smaller presence of foreign companies: the theatre/festival has to estimate the cost of bringing those companies plus that of surtitling, or the revenue they will get if no surtitling is offered, and this will be the determining factor. Even the people at the Teatre Lliure in Barcelona, which makes the greatest use of theatre surtitling in Spain and will be programming several surtitled plays in its new season, claim that this question is in fact related to the theatre's artistic policy (a desire to make foreign theatre more widely known in Barcelona), rather than to the direct influence of the introduction of surtitling. Two of the theatres participating in the questionnaire, however, did acknowledge the contribution of surtitling to their programming more companies from abroad.

This varying, perhaps insufficient, recognition for the impact theatre surtitling may have on theatres' and festivals' programmes is paralleled by the invisibility characterising this translation type in reviews and theatre writings. In an article about the history of theatre festivals in Colombia (Reyes 2006), focusing on the Festival Iberoamericano de Teatro de Bogotá, for instance, there is no single mention of surtitles, even though the writer analyses the reception of plays by Chéjov, Meyerhold, Gogol and Tolstoi, as well as by Ibsen, Shakespeare and Beckett, all performed in languages other than Spanish. The programme on this important festival's webpage reads - in big typeface along the bottom of the page -: "Las obras en otros idiomas tendrán subtítulos [sic] en español o traducción simultánea" ["Works in languages other than Spanish will have Spanish subtitles [i.e. surtitles] or simultaneous translation"] (translation MM), but neither surtitling nor simultaneous translation deserve a mention in the section concerning the history of the Festival on the website, despite the fact that it boasts the presence of 520 companies from 50 different countries in its 16 years' history. This contrasts with the title of a paper presented by Markus Luchsinger, from the Berliner Festspiele, at the 2004 Languages and the Media Conference in Berlin, which stated: "Surtitling: the Most Important Incidental in International Theatre".

Intralingual surtitling - the object of another question ${ }^{17}$ - is very rarely used in theatre, only occasionally for the deaf and hard of hearing. The people at Barcelona's Festival Grec state that their festivals normally have, for each of the productions programmed, one special performance for the blind and another one for the deaf in which they provide intralingual surtitles. As regards other linguistic matters, the Teatre Lliure does have fixed shows offering interlingual surtitling: Catalan performances are surti- 
tled in Castilian Spanish and in English two days per week. The Teatro Español in Madrid too has often surtitled plays performed in languages other than Castilian but also spoken in Spain, e.g. Catalan and Galician. It is, however, the impression of the people taking care of this issue in some of the Spanish theatres interviewed that audiences prefer e.g. Catalan productions to be performed in Castilian Spanish, rather than surtitled, not because of any (political) rejection of the Catalan language they would be hearing in the latter case, but because they get greater enjoyment from performances in their own language. This shows that the source language of the text, and the target context, may determine the target receivers' preferences regarding the translation type for a particular genre.

The last two points of the questionnaire focused on reception ${ }^{18}$. It is generally agreed by the respondents who took part in it that audience reaction towards surtitling is highly favourable; moreover, theatre goers frequently inquire whether a foreign show will be surtitled, and complain if it is not. Programmes and bills, therefore, normally mention whether surtitling will be provided for a particular show. Interestingly then, the division that surtitling initially caused among opera goers - i.e. between those who found it intrusive and unnecessary and those who welcomed it enthusiastically - appears not to have been replicated in theatre audiences, who seem to accept that this is the only way to see foreign companies performing in the original language. This poses a curious paradox, though, which Carlson (2000: 83) adequately describes:

I am aware of little such controversy surrounding the use of supertitles in the spoken theatre [as there was in opera. ...]. Supertitles [...] are much more actively disruptive [than simultaneous translation], since they are directly competing with other stimuli to the visual channel, leaving unimpeded the auditory channel. This is not nearly so serious a problem in opera, where the auditory contribution of the music is central, as it is in the theatre, where the unimpeded auditory channel is essentially receiving only the language which presumably cannot be understood. Thus in the spoken theatre the supertitle leaves open the reception channel it is designed to replace and blocks the major one not involved in the problem it seeks to solve.

The reasons Carlson (2000: 83-84) gives for the smoother introduction of surtitling in the spoken theatre are that, as it "relies much more heavily and directly upon language, $[\ldots]$ accessibility to that language is distinctly more important [than in opera]", and that, as the repertoire of opera is much smaller than that of drama, opera-goers often know it well. Moreover, the heavy load that the spoken language bears in drama - if compared to opera, in which the verbal text as such is secondary to the fusion of music and words - may, in my view, actually preclude the introduction of intralingual surtitling in it, since this would probably be felt as too redundant: the problem of diction and comprehension is obviously not so present in spoken 
theatre as it is in opera (theatre audiences would probably not accept being confronted with it), so the need for clarification of the actors' speeches by duplicating them on a screen does not seem so compelling.

Nevertheless, the assessment of surtitles seems to be a more complex issue than the acceptance of surtitling as such. As an overt type of translation, surtitling lays itself "bare to criticism from everybody with the slightest knowledge of the source language", like subtitling (Gottlieb, 1997: 108). This is particularly noticeable in the case of international theatre festivals, in which the presence of members of the audience who are familiar both with the foreign language heard on the stage and with that which is projected on the screen is not at all uncommon. As happens with subtitles (Gottlieb, 1997: 74), the feedback effect this produces is often negative. This type of spectator can be very critical, although assessment parameters on the part of the audience may also include other aspects than language, such as legibility and synchronicity, as was pointed out by the surtitling firm '36caracteres' in their answer to my questionnaire:

La retroalimentación que recibimos es positiva [...]. No obstante, depende de la calidad de los sobretítulos. Al público le gustan si la traducción es buena, si el ritmo de lectura permite seguir la representación con comodidad, si tienen buena legibilidad, etc.

[The feedback we get is quite positive... Nevertheless, it depends on the quality of the surtitles. Audiences like them if the translation is good, if the reading pace allows them to follow the performance comfortably, if legibility is good, etc.] (Translation MM)

As far as a possible impact on the size of the audience is concerned, there is not much agreement in the answers provided: while some of the theatres consider that the presence/absence of surtitling does not determine the size of the audience in foreign language productions, others like the people responsible at the Festival Grec think that the absence of surtitling implies limiting the audience of those productions mostly to e.g. the French or German community in Barcelona.

In those cases in which the questionnaire actually took the form of a telephone interview, the answers to this last point yielded some useful information concerning the relationship between surtitling and production. Thus, the decision whether or not to introduce surtitling is often a negotiation between the different agents involved: mainly, the festival organizers and/or theatre management and the company's artistic director, who may utterly refuse to have surtitling in the production, as mentioned above, or only agree to have, say, $60 \%$ of the text surtitled. This may also be related to the type of play/scene: if it has a strong visual component, then it is not considered very suitable for surtitling, as this is a visually intrusive translation tool. As Karamitroglou (2000: 78-9) explains, 
[t]he translation of the textual/linguistic part of an audiovisual product is determined $[\ldots$ in addition, ...] by the emphasis it puts on the visual-and-aural elements vs. the textual/linguistic ones, namely whether in the particular audiovisual production it is the people/action or the language/dialogues that are central.

A good example of this has been provided by a current production at the Teatro Español in Madrid, a play about Afghanistan performed in several languages, including Pashtun. After taking great pains to have some speeches in the Afghan language of one particular scene translated into Spanish in order to be surtitled, the director and theatre management finally decided to withdraw the surtitles from this scene for the following reasons: first, the visuals were sufficiently clear; second, the English characters present in the scene did not understand the dialogue either; and finally, an important issue in matters of reception, the written communication of the surtitles would in fact detract the attention from the effect intended, for the scene was one characterized by screaming, shouting insults, and the production of all sorts of verbal aggression.

Audience reaction to the presence/absence of surtitling is also connected with genre differences. Two recent foreign-language productions at the same theatre in Madrid (from the USA and from Poland) had no surtitles since both directors refused to have them. The American performance went down well as it was a very musical and visual one. This was also the general expectation for the Polish one, which in fact turned out to be a 'normal' play, with a strong spoken component, and became unbearable to some members of the audience who left half-way through the performance.

I would like to finish this article by referring to some new, provocative uses to which surtitling has been put in two theatre productions described by Carlson (2000: 87-90) ${ }^{19}$, opening up innovative, and certainly challenging, possibilities for this audiovisual translation type. Contrary to the general concept of surtitles as an intrusive but essentially neutral device as far as its contribution to meaning is concerned, some theatre directors have seen them as "another element in the multi-channeled reception experience offered by the theatre [and, as such,] a potential ground for the production of additional meanings" (Carlson 2000: 85). Surtitling is then subjected to a process of defamiliarization, forcing audiences to see it as "something other than an accepted convention, and a transparent conveyer of meanings identical to those expressed in another language by the actors" (ibid.: 87): in these productions, the surtitles at times display stage directions - which thus keep their original written form, rather than being converted into kinesic, proxemic or aural signs on the stage, as is usually the case - or provide lines which are clearly at odds with what is being said or seen on the stage; the screen may also display lines which are not actually spoken at the same time, or may be used as a prompter to an actor who seems to have forgotten a line; and an actor may read cue designations (i.e. characters' names) while the corresponding character's lines appear on the 
screen. As Carlson states, in this "metatheatrical playfulness", "the supertitles play a major role" (ibid.: 89).

\section{Conclusion}

With this analysis of surtitling from a macrostructural perspective, I have tried to show the evolution experienced by this audiovisual translation type in the context which first incorporated it, as regards production, reception, technological changes and the part that language transfer plays in it now, i.e. its new role as a communication facilitator not involving translation. I have discussed some aspects relating to newer consumers of surtitles, theatre audiences, and a few of the factors that determine the process of surtitling in the spoken-theatre world. Apart from providing researchers with interesting material for the study of the way in which AVT works, the theatre context has also supplied surtitling with a new role, one in which it functions in a clearly unconventional manner. Theatre originally 'borrowed' surtitles from opera and has meanwhile adapted them to its own purposes, although to this day practice remains varied and variable. Opera is not very likely to now borrow these new and provocative uses back: as the article has hopefully also shown, surtitling - like other AVT types - is determined not just by the transmission channel but also by other factors such as genre differences, audiences' attitudes and beliefs, aesthetic norms and the power relations established in the specific target situation.

The analysis of surtitling in context also has theoretical implications regarding the norms which govern or should govern the final shape of surtitles and the concept the various participants have of these (translation) products. Further reception studies are obviously needed, for which relevance theory may surely prove useful, contributing to our understanding of the process and products of surtitling in the same way as translation theories and methodologies such as Descriptive Translation Studies and functional approaches have largely done so far.

\section{Bibliography}

Bonwit, Stuart (1998). "Mac at the Opera". www.wap.org/journal/surtitles/surtitles.html. (last visited on 6 September 2007).

Bourdieu, Pierre (1988 [1979]). La distinción. Criterios y bases sociales del gusto. Madrid: Taurus. Carlson, Marvin (2000). "The Semiotics of Supertitles". Assaph. Studies in the Theatre 16, 77-90.

Clements, Andrew (2000). "Incomprehensible". The Guardian, 23 Sept.

Dewolf, Linda (2001). "Surtitling Operas. With Examples of Translations from German into French and Dutch". Y. Gambier \& H. Gottlieb (2001), 179-188.

Diario de Sesiones del Senado. (1999) VI Legislatura. Comisiones. Núm. 443. http:www.senado.es/boletines/CS0443.html. (last visited on 6 September 2007).

Díaz Cintas, Jorge (2003). Teoría y práctica de la subtitulación. Inglés - Español. Barcelona: Ariel. Everett-Green, Robert (2004). "A Surfeit of Surtitles". The Globe and Mail, Canada, 5 Jan.

Festival Iberoamericano de Teatro de Bogota. http://www.festivaldeteatro.com.co/xfestival/inicio /index.html .(last visited on 6 September 2007). 
Gambier, Yves (2003). "Introduction. Screen Transadaptation: Perception and Reception”. Y. Gambier (ed.) (2003). Screen Translation. Manchester: St Jerome. Special Issue of The Translator 9 (2), 171-189.

Gambier, Yves \& Henrik Gottlieb (eds) (2001). (Multi)media translation. Concepts, Practices, and Research. Amsterdam/Philadelphia: John Benjamins.

Gambier, Yves \& Henrik Gottlieb (2001). "Multimedia, Multilingua: Multiple Challenges”. Gambier \& Gottlieb (2001), viii-xx.

Gottlieb, Henrik (1997). Subtitles, Translation \& Idioms. PhD Thesis. University of Copenhagen.

Karamitroglou, Fotios (2000). Towards a Methodology for the Investigation of Norms in Audiovisual Translation. The Choice between Subtitling and Revoicing in Greece. Amsterdam/Atlanta: Rodopi.

Low, Peter. (2002). "Surtitles for Opera. A Specialised Translating Task". Babel 48 (2), 97-110.

Martínez, Patricia (forthcoming). "Opera-titling: Blessing or Burden?". To appear in J. W. Davidson \& A. M. Trippett (eds) La púrpura de la rosa. Bringing a Latin Baroque Opera to Life (provisional title). Durham University: Durham Modern Languages Series.

Mateo, Marta (2001). "Performing musical texts in a target language: the case of Spain". Across Languages and Cultures 2 (1), 31-50.

Mateo, Marta (2002). "Los sobretítulos de ópera: dimensión técnica, textual, social e ideológica". J. Sanderson (ed.) (2002). Traductores para todo. Actas de las III Jornadas de doblaje y subtitulación. Alicante: Universidad de Alicante, 51-73.

Mateo, Marta (2007). "Reception, text and context in the study of opera surtitles". Y. Gambier, M. Shlesinger \& R. Stolze (eds). Doubts and Directions in Translation Studies. Amsterdam: John Benjamins, 169-182.

Mejías, Enrique (2005). "La Parranda; Murcia llega a Madrid. http://www.diariodirecto.com/hem/ 20050813/CUL/parranda_zarzuela.html. (last visited on 6 September 2007).

Nepomuceno, M. Angel (2004). "Don Juan de infausta memoria". Diario de León: Edición Digital, "Cultura", Viernes, 25 de junio de 2004. www.diariodeleon.es/hemeroteca/noticia.jsp. (last visited on 21 July 2004)

Reyes, Carlos José (2006). "Festivales de cara al mundo". Primer acto. Cuadernos de investigación teatral 315 (4), 153-161.

Virkkunen, Riitta (2004). “The Source Text of Opera Surtitles”. Meta 49 (1), 89-97.

${ }^{1}$ For the evolution of terminology in AVT, from film translation to multimedia translation, through screen and audiovisual translation, see Gambier 2003: 171.

${ }^{2}$ As Dewolf (2001: 187) states, "[r]ecognising the role of new technologies in the dissemination and enjoyment of stage productions, titles have done more than anything else to increase the size of the audience".

${ }^{3}$ Some surtitling firms in fact recommend their clients to protect themselves from possible financial loss by "purchasing insurance to cover loss of ticket revenue due to refunds being demanded [or] printing a disclaimer in your programme excluding titles as part of the entertainment paid for" (this was the suggestion made by the Canadian firm Aria Nuova in an earlier version of their webpage: www.aria-nuova.com/projtech.html). This reinforces my impression that opera audiences do not consider surtitles as a mere bonus but, more and more, as an essential part of their entertainment.

4 "Como ustedes saben, en la actualidad los grandes teatros, cuando se representa una ópera en otra lengua -y yo abogaría porque [sic] se hiciera lo mismo en la zarzuela, aunque sea en castellano porque la voz cantada no se entiende demasiado bien-, tienen un sistema de sobretítulos en el que se lee, por lo menos, un resumen de lo que está aconteciendo" (see Diario de Sesiones de Senado, 1999)

${ }^{5}$ This is a personal impression grounded on various newspaper articles, on surtitling firms' websites providing a brief history of the introduction of surtitling in Canada, the USA and Europe (e.g. http://www.aria-nuova.com, http://www.prescott.it, http://www.surtitles.com), and on the above-mentioned letters to the editor published in British newspapers which illustrated the controversy surtitling initially originated in that country, as opposed to its smooth introduction in Spain (see Mateo 2002 for a more detailed study of these differences). 
${ }^{6}$ We may here quote this extract from a review of Don Giovanni in León, Spain (Nepomuceno, 2004): "Programar ópera sin subtitulaje ha sido uno de los graves fallos de esta programación lírica que ha planificado el Auditorio "Ciudad de León". [...] En ningún lugar del mundo, a no ser aquí, se les ocurre en estos tiempos programar ópera sin subtítulos. ¿De qué sirve gastarse los millones si luego no sabemos sacarle la debida rentabilidad? No se puede acercar la ópera a una afición novel en este campo y además pretender que sea políglota. La ópera ya es de por sí selectiva como para hacerla aún más con el idioma." [Programming opera with no subtitling (i.e.surtitling) has been one of the great failures of the music programme planned by the Auditorium Ciudad de León [...] Nowhere else in the world but here do organizers have the brilliant idea to have opera with no subtitling (i.e. surtitling). What is the point of spending millions if we won't achieve a return on them? You can't bring opera closer to an audience who are laymen in the field and expect them to speak several languages too. Opera is selective per se; you don't need to make it even more so with the language."] (translation MM).

${ }^{7}$ The question was: "¿no creéis que con la cantidad de gente de fuera que asiste a las funciones gente de toda España que no hablamos catalán y gente del extranjero- sería más lógico poner el sobretitulado principal en castellano, para que la mayoría [...] pudiera seguirlo? Sobre todo en óperas más infrecuentes [...]?" [“Don't you think that, considering the large number of people from outside Barcelona who attend the Liceu's performances - people from all over Spain who, like me, do not speak Catalan and people from abroad -, it would be more logical to project the main surtitling in Castilian Spanish, so that the greatest part of the audience could understand it? Particularly in the case of the less common operas"] (translation MM).

8 "Si no existe la posibilidad de contar con varios idiomas parece lógico que esté en castellano." "Yo veo bien que lo subtitulen en catalán. Es su idioma materno." "Mejor la sobretitulación en ambas lenguas y todos contentos." "Dado que es un teatro catalán y ambos idiomas (catalán y español) son cooficiales, me parece bien que el teatro elija." "La solución del Liceo es la perfecta con las pantallas individuales. Una respuesta colectiva que responde a intereses generales y múltiples respuestas individuales para que cada uno haga lo que le venga en gana, sin imposiciones." ["If it is not possible to have several languages, it seems logical to have it in Castilian." "I agree with their surtitling it in Catalan. It is their native language." "It would be better to have the surtitling in both languages and keep everybody happy." "As it is a Catalan theatre and both languages (Catalan and Castilian) are official languages there, I think the theatre has every right to choose." "The Liceu's solution with individual screens is the perfect one. A collective response, answering general interests, and multiple individual responses so that everyone can do whatever they like, without imposition."] (translation MM).

9 "Si [los paneles individuales] son como me imagino y hay que levantar y bajar la vista para atender a las dos cosas, puedes acabar con un dolor de cervicales considerable, y haberte perdido cosas interesantes en la escena." "[Los paneles individuales] es SIN DUDA la mejor opción, ya que puedes seguir la ópera en varios idiomas. No es molestia alguna, acaso desvías los ojos como haces para los sobretítulos... y LO MEJOR es que, al ser pantallas de plasma, sólo veías la tuya, las de los de alrededor no te molestaban para nada... (ya que a partir de cierto ángulo no se ve nada...)." (original highlighting) ["If individual screens are what I imagine they are like, and you have to raise and lower your eyes in order to pay attention to both things, you may end up with intense neck pain, after having missed interesting things from the stage." "[Individual screens] are UNDOUBTEDLY the best option, as you can follow the opera in several languages. They cause no discomfort at all, you may perhaps have to look away as you do for above-the-proscenium surtitling ... and THE BEST THING is that, since the screens are plasma display panels, you only saw yours, the neighbouring screens did not disturb you at all... (for you can't see anything from a certain angle...).”] (translation MM).

10 "¿Para qué quieres tú un sistema de subtitulación si te las sabes todas de memoria???" ["What do you want a subtitling system for, if you know them all by heart???"] (translation MM).

11 "Para cuando me toque ver un Britten, un Janacek, un Korngold, un Stravinsky... esas no me las sé... Para las italianas..., [...] me es un poco lo mismo. Si me los ponen, mejor que mejor, pero si no..." ["For productions in which I have to watch a work by Britten, or by Janacek, or Korngold, or Stravinsky ... [all right, since] I don't know those... For the Italian ones ..., I don't really care. If they have surtitles for them, so much the better, but if they don't..."] (translation MM).

${ }^{12}$ As the present article was being printed, I was informed of the existence of two books on theatre surtitling which I was not aware of: Yvonne Griesel, 2000. Translation im Theater, Frankfurt a. M.: Lang; and, a more recent one by the same author which will actually be reviewed in the pre- 
sent volumen, Yvonne Griesel, 2007. Die Inszenierung als Translation, Berlin: Frank \& Timme.

${ }^{13}$ I would like to express my thanks to surtitler Eduard Bartoll, the surtitling firm ' 36 caracteres', Àngels Queralt at the Festival Grec in Barcelona, Isabel Barceló at the Festival Internacional de Teatro Clásico de Almagro, Mamen Adeva at Madrid's Festival Escena Contemporánea, Gonzalo Audeole at the Teatro Cervantes in Málaga, Natalia Feijoo at the Teatro Español in Madrid, the surtitling department at the Teatre Lliure in Barcelona, and Nicholas Jackson at the British Council in Madrid. My gratitude also goes to Begoña Cires, the person responsible for the zarzuela festival in Oviedo, who answered a similar questionnaire over the telephone and whose comments proved very useful for the previous section of this article.

14 “1. ¿Quién hace el encargo de los sobretítulos: ustedes o la compañía extranjera? [Who commissions the surtitles: is it you (the theatre/festival organisers) or the foreign company?] 2. ¿A quién se los encargan?: un departamento del festival/teatro, traductores especializados, etc." [Who is commissioned to do them?: a special department in the festival/theatre, freelance translators specialized in surtitling, etc"] (translations MM).

15 “3. ¿Qué sistema se usa para hacerlos? ¿Y para proyectarlos? ¿Quién se encarga de la proyección durante la representación: el traductor que ha hecho los sobretítulos u otra persona? [What is the system used to make the surtitles? And to project them? Who takes care of the projection during the performance: the surtitler or a different person?] 4. Si se producen cambios inesperados durante la función, ¿no se proyecta el sobretítulo correspondiente o se proyecta el que estaba preparado, aunque no se corresponda con lo que estén diciendo/esté pasando?" [If unexpected changes occur during the performance, is no surtitle projected for that speech or do you still project the originally planned surtitle, even if it does not correspond with what is being said/is happening?] (translations MM).

16 " 5 . ¿Creen que desde que hay sobretítulos hay más obras en lengua extranjera en su festival/teatro? (es decir, ¿han influido los sobretítulos en la presencia de compañías extranjeras en el festival/teatro?)" [Do you think that your theatre/festival has programmed more foreignlanguage works ever since it introduced surtitles? (i.e. have surtitles had an impact on the presence of foreign companies in your festival/theatre?)] (translation MM).

17 “6. ¿Alguna vez proyectan sobretítulos en la misma lengua de la representación?” [Do you ever project surtitles in the same language as that of the performance?] (translation MM).

18 “7. ¿Creen que al público le gustan los sobretítulos?; es decir, ¿cuál es la reacción del público: favorable, no favorable, indiferente? [Do you think people enjoy surtitles?; i.e. what is the audience's response like: favourable, unfavourable, indifferent?] 8. ¿Se puede observar una diferencia en el número de espectadores cuando se ofrecen/no se ofrecen sobretítulos?" [Can a difference in the size of the audience be observed when surtitles are/are not offered?] (translations MM).

${ }^{19}$ Frank Castorf's 2001 adaptation of Tennessee Williams's A Streetcar Named Desire for the Berlin Volksbühne, and a 2000 production of King Lear by the Belgian Needcompany. 